\title{
Deteksi Kontaminasi Bovine Viral Diarrhea Virus pada Fetal Bovine Serum yang Tersedia secara Komersial
}

\author{
(THE DETECTION OF BOVINE VIRAL DIARRHEA VIRUS CONTAMINATION IN \\ COMMERCIALLY AVAILABLE OF FETAL BOVINE SERUM)
}

\author{
Hastari Wuryastuty ${ }^{1 *}$, Sri Handayani Irianingsih ${ }^{2}$, Raden Wasito ${ }^{3}$ \\ ${ }^{1}$ Departemen Ilmu Penyakit Dalam, ${ }^{3}$ Departemen Patologi, \\ Fakultas Kedokteran Hewan, Universitas Gadjah Mada. \\ Jl. Fauna No. 2 Karangmalang, Yogyakarta, Indonesia 55281. \\ ${ }^{2}$ Laboratorium Virologi, Balai Besar Veteriner Wates, \\ Jl. Raya Yogya-Wates km 27, TP 18 Giri Peni, \\ Wates, Kulon Progo, Yogyakarta, Indonesia \\ *Email: hastari@ugm.ac.id; HP: 0811256195,
}

\begin{abstract}
ABSTRAK
Teknik diagnostik menggunakan kultur sel merupakan gold standard untuk menentukan penyebab utama suatu penyakit terutama yang disebabkan oleh virus seperti bovine viral diarrhea virus (BVDV). Prosedur kultur sel memerlukan suplementasi serum pada media pertumbuhan. Serum yang digunakan sebagai suplementasi umumnya berasal dari hewan spesies yang sama agar sel dapat tumbuh sesuai dengan habitatnya. Serum yang paling umum digunakan dalam teknik kultur sel adalah fetal bovine sera (FBS) karena kandungan faktor pertumbuhannya yang tinggi. Infeksi BVDV sering terjadi pada populasi sapi. Infeksi BVDV in utero menyebabkan materi (serum, sel dan jaringan) yang berasal dari fetus sapi terkontaminasi BVDV. Penelitian telah membuktikan bahwa dua dari sepuluh sampel FBS dengan merek dagang yang berbeda, menunjukkan hasil positif terhadap virus BDV dengan uji polymerase chain reaction.. Isolasi terhadap BVDV dari FBS yang positif dilakukan pada kultur sel Madin-Darby bovine kidney (MDBK), dilanjutkan dengan pengecatan menggunakan uji immuno peroxidase monolayer assay, memberikan hasil negatif. Meskipun BVDV yang terkandung di dalam FBS sampel tidak bereplikasi, tetapi hasil ini tidak dapat diekstrapolasikan untuk setiap produk FBS yang tersedia secara komersial. Berdasarkan hasil tersebut disarankan adanya pengujian rutin terhadap kemungkinan terjadinya kontaminasi oleh BVDV yang dapat berpengaruh pada hasil diagnostik di suatu laboratorium.
\end{abstract}

Kata-kata kunci: kultur sel; bovine viral diarrhea virus; fetal bovine sera; polymerase chain reaction; immuno peroxidase monolayer assay

\begin{abstract}
Diagnostic techniques using cell culture is considering to be the gold standard for detecting the main causes of a disease, especially those caused by viruses such as bovine viral diarrhea virus (BVDV). Cell culture procedures require serum supplementation on growth media. Serum used as supplementation generally comes from animals of the same species so that cells can grow in accordance with their habitat. The most common serum used in cell culture techniques is fetal bovine sera (FBS) because of its high in growth factor level. Bovine viral diarrhea virus (BVDV) infections often occur in cattle populations. BVDV infection in utero causes material (serum, cells and tissues) originating from cow fetuses to be contaminated with BVDV. Research has proven that two out of ten FBS samples with different trademarks positive contaminated with BVDV using polymerase chain reaction tests. Isolation of BVDV from the same FBS grown in Madin-Darby bovine kidney (MDBK) cell culture, followed by staining using the immuno peroxidase monolayer assay test gave negative results. Even though BVDV found in the FBS is not alive, these results cannot be extrapolated for every commercially available FBS product. Based on these results it is recommended that routine testing of the possibility of contamination by BVDV that can affect the diagnostic results in a laboratory.
\end{abstract}

Keywords: cell culture; bovine viral diarrhea virus; fetal bovine sera; polymerase chain reaction; immuno peroxidase monolayer assay 


\section{PENDAHULUAN}

Bovine viral diarrhea (BVD) merupakan penyakit pada sapi yang disebabkan oleh virus genus Pestivirus famili Flaviridae. Penyakit ini mengakibatkan kerugian ekonomis utama pada industri sapi perah maupun sapi potong di seluruh dunia termasuk Indonesia (Darweesh et al., 2015).

Infeksi virus Bovine viral diarrhea (BVDV) pada sapi-sapi di Indonesia secara umum ditentukan berdasarkan adanya antibodi antiBVDV dalam serum dengan menggunakan uji enzyme-linked immunosorbent assay (ELISA) dan deteksi virus BVDV dengan menggunakan uji antigen-capture enzyme-linked immunosorbent assay (ACE), polymerase chain reaction (PCR) serta isolasi BVDV menggunakan MadinDarby bovine kidney atau bovine turbinate sel. Teknik kultur sel hingga saat ini masih merupakan "gold standard" untuk diagnosis penyakit BVD (Wasito et al., 1992; Supriyadi et al., 2008; Sudarisman, 2011). Fetal bovine serum (FBS) merupakan salah satu komponen utama media nutrisi yang paling banyak digunakan dalam teknologi kultur sel atau teknologi pembuatan vaksin (Polak et al., 2008). Hal ini terutana karena FBS memiliki kandungan faktor pertumbuhan, hormon dan nutrien lain dalam jumlah yang lebih tinggi dibandingkan serum yang berasal dari hewan lain yang esensial untuk proliferasi berbagai jenis kultur sel (Hawkes, 2015), di samping semua keunggulan yang dimiliki FBS, serum sebagai produk darah juga dapat merupakan sumber potensial kontaminasi berbagai mikroorganisme sehingga berisiko apabila digunakan dalam sistem kultur sel. Bovine Viral Diarrhea yang disebabkan oleh BVDV merupakan penyakit menular yang paling signifikan dalam industri peternakan di seluruh dunia karena tingkat kejadiannya yang tinggi, persistensinya yang kuat, dan konsekuensi klinisnya yang buruk. Bovine Viral Diarrhea Virus juga merupakan kontaminan yang paling signifikan pada kultur sel mamalia karena kemampuan virus tersebut dalam melintasi barier plasenta masuk kedalam sirkulasi fetus, menginfeksi fetus dan mengkontaminasi FBS (El-Dakhley et al., 2015). Hal tersebut akan berakibat FBS menjadi tidak layak digunakan sebagai suplemen nutrien dalam kultur sel karena menghambat ketepatan diagnosis dan efisiensi penggunaan vaksin (Bauermann et al., 2013; Xia et al., 2013). Oleh karena itu, uji tapis/ skrining terhadap produk FBS komersial penting dilakukan sebelum bekerja dengan virus BVD (OIE, 2015).

Penelitian ini bertujuan untuk mempelajari kemungkinan adanya kontaminasi virus penyebab BVD pada FBS komersial yang umum digunakan di laboratorium kultur sel. Harapannya penggunaan bahan yang terkontaminasi dalam sistem kultur sel dapat dicegah.

\section{METODE PENELITIAN}

Materi Penelitian. Sepuluh sampel FBS komersial, dengan merk dagang dan nomor produksi berbeda yang digunakan untuk kultur sel di beberapa laboratorium di Universitas Gadjah Mada, Yogyakarta digunakan sebagai sampel penelitian.

Ekstraksi RNA dari Sampel. Ekstraksi terhadap RNA BVDV dilakukan dengan menggunakan kit yang tersedia secara komersial (Viral Nucleic Acid Kit II, Geneaid ${ }^{\mathrm{TM}}$ ) (Geneaid, 2017) dan dikerjakan sesuai dengan instruksi penggunaan. Ekstraksi RNA yang dihasilkan digunakan untuk uji RT-PCR menggunakan MyTaq ${ }^{\mathrm{TM}}$ One-Step RT-PCR kit (Bioline, Meridian Bioscience, Australia).

\section{Uji Reverse Transcriptase Polymerase Chain Reaction (RT-PCR)}

Sepasang primer yang spesifik mengamplifikasi gen 5'-UTR virus bovine viral diarrhea digunakan pada penelitian ini (Forward 5'-ATG CCC WTA GTA GGA CTA GCA-3' dan Reverse 5'TCA ACT CCA TGT GCC ATG TAC-3') (Vilcek et al.,1994). Amplifikasi genom virus dilakukan dalam tabung tunggal dengan satu enzim RTPCR. Kedalam setiap tabung PCR dimasukkan $25 \mu \mathrm{L}$ MyTaq $^{\text {TM }}$ One-Step mix (2x), $1 \mu \mathrm{L}$ RiboSafe RNase Inhibitor $(10 \mathrm{U} / \mu \mathrm{L}), 2,5 \mu \mathrm{L}(10 \mathrm{pMol})$ masing-masing forward primer dan reverse primer, $0,5 \mu \mathrm{L}(1 \mathrm{U} / \mu \mathrm{L})$ enzym reverse transcriptase, $5 \mu \mathrm{L}$ ekstrak RNA dan diethyl pyro carbonate (DEPC)-treated $\mathrm{H}_{2} \mathrm{O}$ hingga total volume keseluruhan berjumlah $50 \mu \mathrm{L}$. Amplifikasi dilakukan di dalam mesin personal combi thermocycler (Biometra, 37079 Goettingen, Germany) dengan kondisi siklus reaksi sebagai berikut: campuran reaksi awalnya diinkubasi satu siklus selama 30 menit pada temperatur $60^{\circ} \mathrm{C}$ dilanjutkan dengan denaturasi awal pada temperatur $94^{\circ} \mathrm{C}$ selama dua menit dan 35 siklus amplifikasi yang masing-masing terdiri dari tahap denaturasi 
pada temperatur $94^{\circ} \mathrm{C}$ selama 30 detik, tahap annealing pada temperatur $55^{\circ} \mathrm{C}$ selama 30 detik dan tahap ekstensi pada temperatur $70^{\circ} \mathrm{C}$ selama satu menit dan diikuti satu siklus tahap ekstensi akhir pada temperatur $70^{\circ} \mathrm{C}$ selama tujuh menit. Produk amplifikasi dianalisis dengan elektroforesis pada agarose gel 1,5\% dengan kecepatan $120 \mathrm{v} 400$ A selama 45 menit. Agarose gel kemudian direndam di dalam larutan Tris-borate-EDTA ${ }^{\mathrm{TM}}$ (Sigma-Aldrich) bufer $1 \mathrm{x}$ ditambah dengan $0,5 \mu \mathrm{g} / \mathrm{mL}$ larutan ethidium bromida ${ }^{\mathrm{TM}}$ (Sigma-Aldrich) selama 15 menit. Produk elektroforesis yang telah diwarnai kemudian divisualisasi menggunakan ultra violet transiluminator dan direkam menggunakan Gel Logic 100 Imaging System (Kodak, Carestream Health Inc. Rochester, NY 14608).

\section{Isolasi Virus Bovine Viral Diarrhea}

Sebanyak $50 \mu \mathrm{L}$ suspensi sel Madin-Darby Bovine Kidney (MDBK) konsentrasi $125.000 \mathrm{sel} /$ $\mathrm{mL}$ ditumbuhkan pada pelat mikro 96 sumuran berdasar rata. Sebanyak $100 \mu \mathrm{L}$ media pertumbuhan yang terdiri dari Minimum Essential Medium Eagle yang mengandung Earle's salt, L-glutamine dan sodium bicarbonate $^{\mathrm{TM}}$ (M-4655 Sigma-Aldrich) yang disuplementasi dengan 10\% FBS bebas BVDV, $1 \mathrm{~mL}$ antibiotik Penicilline-Streptomycine ${ }^{\mathrm{TM}}$ (Gibco) dan $250 \mu \mathrm{g} / \mathrm{mL}$ Ampheteracine $\mathrm{B}^{\mathrm{TM}}$ (Caisson Lab, USA) sebagai anti-jamur kemudian ditambahkan kedalam setiap sumuran. Pelat mikrotiter kemudian dimasukkan kedalam $\mathrm{CO}_{2}$ inkubator untuk diinkubasi pada temperatur $37^{\circ} \mathrm{C}$ dan $5 \% \mathrm{CO}_{2}$ selama 1x24 jam. Sesudah inkubasi, media pertumbuhan diganti dengan media pertumbuhan baru dan sel MDBK yang tumbuh di dalam setiap sumuran diinokulasi dengan 25 $\mu \mathrm{L}$ sampel yang diteliti. Selain sampel yang diuji, serum positif dan negatif BVDV juga disertakan di setiap pelat mikrotiter sebagai kontrol positif dan negatif. Pelat mikrotiter kemudian diinkubasi pada suhu $37^{\circ} \mathrm{C}$ dan $5 \%$ $\mathrm{CO}_{2}$. Untuk efisiensi pertumbuhan dari virus, inkubasi sel dilakukan selama empat hari (Zhang et al., 2016). Setiap hari pertumbuhan sel diamati terhadap adanya efek sitopatik dari virus. Pada penelitian ini, pengamatan selama masa inkubasi tidak ada sampel yang mengakibatkan efek sitopatik pada sel MDBK. Pascainkubasi, media biakan diambil dan disimpan, sel MDBK yang telah diinokulasi dicuci berulang kali dengan larutan PBS dan difiksasi menggunakan 35\% larutan aseton di dalam larutan bufer fosfat yang mengandung 0,02\% bovine serum albumin (BSA).

\section{Immunoperoxidase Monolayer Assay (IPMA)}

Setelah sel MDBK difiksasi, $100 \mu \mathrm{L}$ antibodi monoklonal anti-BVDV (MAbE2gp53IgG2b Isotype, VMRD Inc. PO Box 502, Pullman, WA 99163, USA), yang diencerkan 1:100 dengan akuabides ditambahkan ke setiap sumuran dan diinkubasi selama satu jam (Kozasa et al., 2011). Sesudah inkubasi, pelat mikrotiter dicuci sebanyak tiga kali dengan bufer pencuci (PBS yang mengandung 0,05\% larutan Tween 20). Sesudah pencucian, $50 \mu \mathrm{L}$ protein G-horseradish peroxidase yang telah diencerkan 1:1000 dengan binding buffer ditambahkan ke setiap sumuran dan diinkubasi selama 15 menit pada suhu ruang. Sesudah inkubasi, pelat mikrotiter dikeringkan dan dicuci sebanyak tiga kali dengan bufer pencuci. Sesudah pencucian, 100 $\mu \mathrm{L}$ larutan substrat yang mengandung $280 \mu \mathrm{g}$ 3-amino-9-ethylcarbazole setiap $\mathrm{ml} \mathrm{N}, \mathrm{N}$ dimethyl-formamide (Sigma, UK) sebagai substart dalam $100 \mathrm{~mL} 50 \mathrm{mM}$ bufer asetat $\mathrm{pH}$ 5) dan $0,01 \%$ hidrogen peroksida ditambahkan kesetiap sumuran dan diinkubasi di dalam gelap selama 60 menit pada suhu ruang. Pelat mikrotiter kemudian dikeringkan, dicuci dua kali dengan $\mathrm{H}_{2} \mathrm{O}$, dikeringkan kembali dan diperiksa di bawah mikroskop cahaya.

\section{HASIL DAN PEMBAHASAN}

Hasil uji polymerase chain reaction (PCR) dari fetal bovine serum (FBS) menggunakan pasangan primer spesifik yang mengkode gen 5'UTR dari virus penyebab bovine viral diarrhea (BVD) disajikan dalam Gambar 1. Dari 10 sampel yang digunakan pada penelitian ini dua $(20 \%)$ menunjukkan adanya pita (produk amplifikasi) pada posisi 288 bp yang spesifik untuk BVDV.

Kejadian kontaminasi virus pada serum sapi sering terjadi sehingga tingkat kontaminasi dalam produk serum yang tersedia secara komersial seperti FBS berkisar antara 10\% hingga 75\% (Glangaspero, 2013). Di antara virus yang mengkontaminasi, Bovine Viral Diarrhea Virus (BVDV) merupakan virus yang paling sering ditemukan di dalam FBS yang tersedia secara komersial dibandingkan virusvirus lainnya (Mahmood dan Ali, 2017) dan 


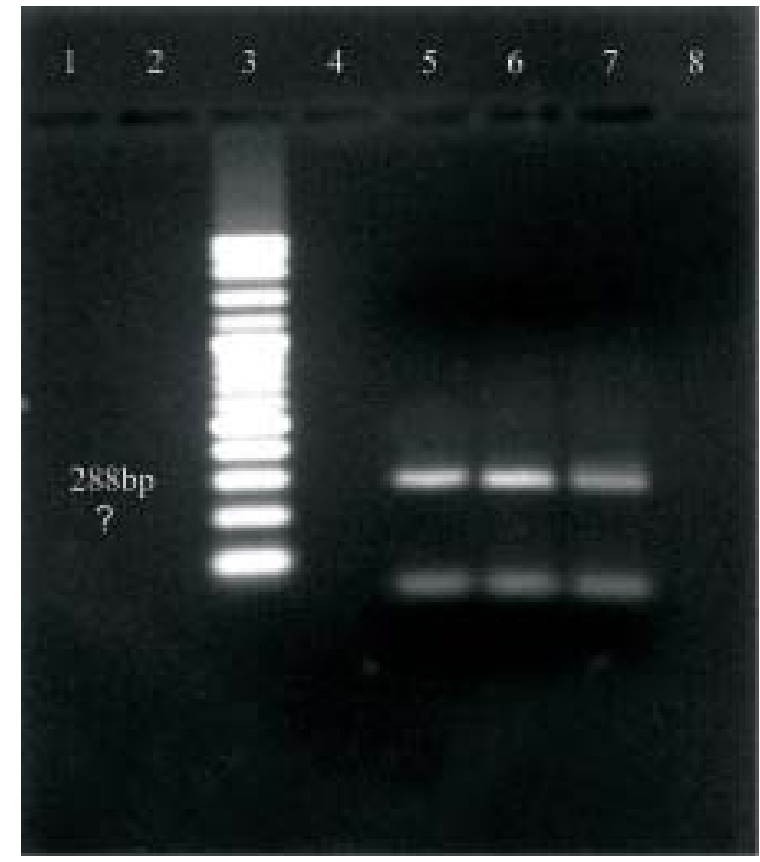

Gambar 1. Deteksi Bovine Viral Diarrhea Virus dengan uji PCR. (Pita 3: Vivantis DNA marker plus $100 \mathrm{bp}$, pita 4: kontrol negatif, pita 5: kontrol positif, pita 6: positif BVDV dari FBS produk 1-G, pita 7: positif BVDV dari FBS produk 1-S, pita 8: negatif BVDV dari FBS produk 3-S).

menimbulkan masalah serius di laboratorium penelitian dan industri materi biologik (Monteiro et al., 2018). Proses filtrasi yang digunakan dalam persiapan memproduksi FBS untuk kepentingan komersial memang mampu mengeliminasi beberapa agen viral yang mungkin terkandung di dalam FBS tetapi BVDV masih mampu melewati hambatan yang ada karena ukurannya sangat kecil dan bentuknya yang berubah-ubah. Oleh karena itu deteksi adanya virus-virus yang mampu melewati filter seperti bovine herpes virus-1 (BHV-1) dan parainfluenza-3 (PI-3) ditentukan melalui observasi efek sitopatiknya (Zabal et al., 2000). Untuk BVDV, seperti diketahui bahwa berdasarkan biotipenya BVDV dibedakan menjadi dua yaitu: 1. Biotipe sitopatik yang mengakibatkan efek sitopatik pada biakan sel sehingga mudah dikenali jika terjadi infeksi karena berdampak rusaknya sel dan 2. Biotipe non-sitopatik yang tidak menimbulkan perubahan morfologik dari biakan sel yang terkontaminasi dan masalah baru muncul setelah beberapa generasi biakan sel. Berdasarkan hal tersebut perlu diterapkan uji spesifik untuk deteksi adanya antigen virus BVDV seperti indirect immunofluorescence atau uji immunoperoxidase monolayer assay (Wuryastuty dan Wasito, 1998; Kozasa et al., 2011). Menurut hasil penelitian Zabal et al. (2000) BVDV di dalam produk serum di Argentina menggunakan metode konvensional hanya terdeteksi 2 dari 20 batches FBS yang tersedia secara komersial. Namun demikian, menggunakan uji kultur sel yang disuplementasi dengan 10\% FBS selama minimal dua minggu menggunakan uji indirect immunofluorescence persentase BVDV yang terdeteksi mencapai 80\% (Polak et al., 2008). Hasil tersebut merupakan bukti bahwa RT-PCR merupakan uji yang cepat untuk deteksi adanya genom virus tetapi tidak dapat membuktikan bahwa virus tersebut hidup dan infeksius (Bazid et al., 2015; Wuryastuti et al., 2018). Dari hasil penelitian-penelitian sebelumnya, BVDV biotipe non-sitopatik lebih banyak dijumpai dibandingkan dengan BVDV sitopatik oleh karena itu kewaspadaan perlu diberikan di dalam mendeteksi adanya kontaminasi BVDV pada setiap batch FBS yang akan digunakan di dalam kegiatan laboratorik.

Pada penelitian ini, empat kultur sel MDBK yang berasal dari pasase berbeda dan telah melalui pengujian terhadap keberadaan BVDV secara molekuler (PCR) dengan hasil negatif digunakan untuk menumbuhkan sampel FBS komersial yang dengan uji PCR telah dibuktikan mengandung genom virus BVD (Wuryastuti, 2018).

Hasil penelitian menunjukkan bahwa menggunakan pengecatan IPMA terhadap sel MDBK yang diinokulasi dengan sampel serum bebas BVDV (Gambar 2) dan yang diinokulasi dengan FBS yang positif terkontaminasi BVDV secara molekuler tidak tampak adanya akumulasi virus BVDV (Gambar 4). Hasil tersebut membuktikan bahwa BVDV yang terkandung di dalam FBS yang tersedia secara komersial pada penelitian ini tidak mampu bereplikasi di dalam sel MDBK. Hal tersebut kemungkinan karena jumlah BVDV yang sangat rendah atau virus sudah dalam keadaan mati selama prosesing pembuatan FBS. Menurut Mahmood dan Ali (2017), virus yang ada di dalam FBS maupun jaringan tidak selalu hidup ketika sel-sel dikultur in vitro, sehingga potensi risiko akan tergantung pada kemampuan virus untuk bertahan hidup dan bereplikasi selama proses penyiapan dan penyimpanan bahan sejak diproduksi hingga 


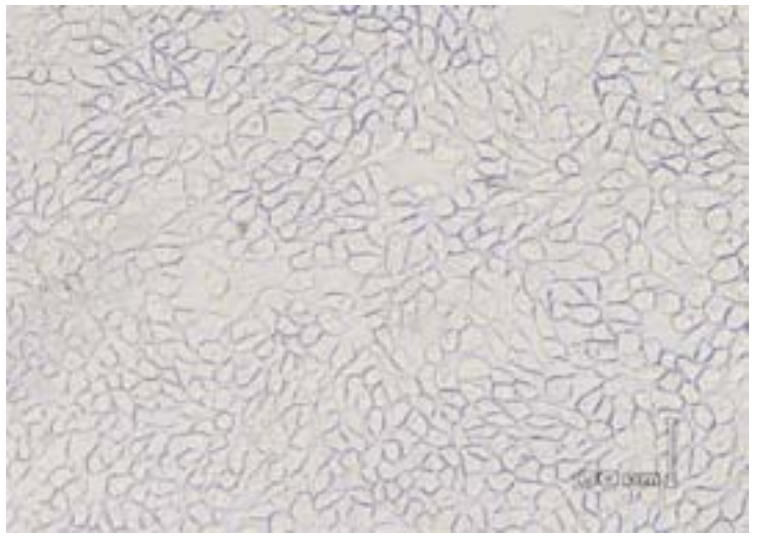

Gambar 2. Hasil pengecatan immuno peroxidase monolayer assay (IPMA) pada sel MDBK yang diinokulasi dengan sampel serum negatif BVDV (kontrol negatif). Sel MDBK tampak membentuk lapisan tunggal dengan tingkat konfluensi 80\% tanpa adanya agregat virus intrasitoplasmik yang terwarnai pada sel MDBK (IPMA, 500 kali). (negatif).

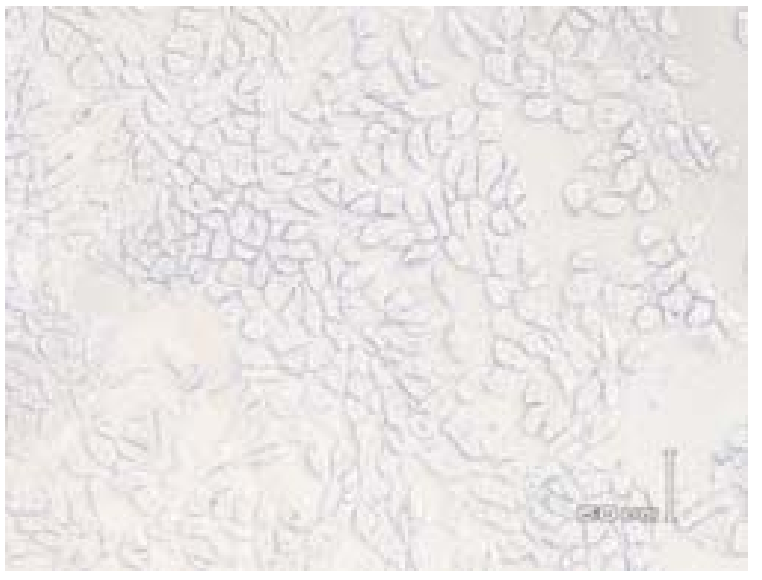

Gambar 4. Hasil pengecatan immuno peroxidase monolayer assay (IPMA) pada sel MDBK yang diinokulasi dengan FBS komersial yang terkontaminasi BVDV. Sel MDBK membentuk lapisan tunggal dengan tingkat konfluensi $80 \%$. Pada daerah intrasitoplasmik sel MDBK tidak terbentuk agregat berwarna kecoklatan (negatif). (IPMA, 500 kali).

digunakan. Pada penelitian yang dilakukan oleh Uryvaev et al. (2012), BVDV virion RNA berhasil terdeteksi $45 \%$ dari 35 FCS komersial yang berasal dari beberapa merek dagang yang berbeda. Pada penelitian tersebut konsentrasi BVDV di dalam serum bervariasi antara $10^{3}$ $10^{7} \mathrm{~g}$-eq $/ \mathrm{mL}$. Lebih lanjut dijelaskan bahwa pemanasan FCS pada suhu $56^{\circ} \mathrm{C}$ selama 30,45 atau 60 menit dapat menurunkan konsentrasi

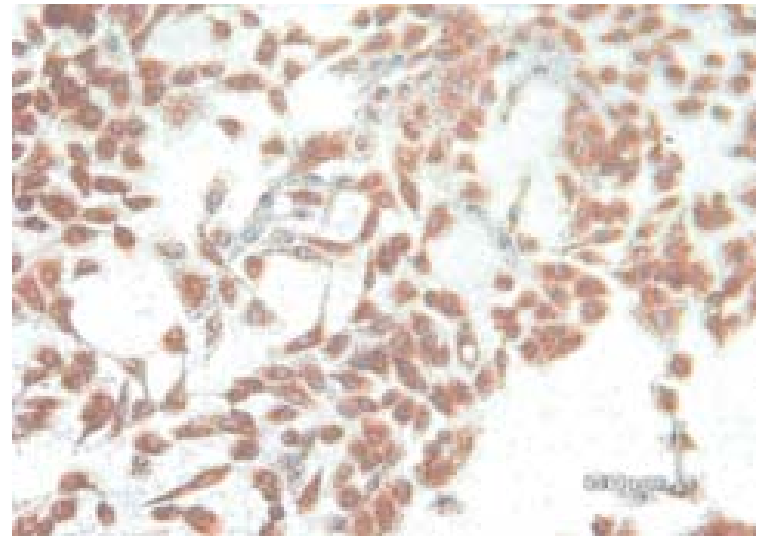

Gambar 3. Hasil pengecatan immuno peroxidase monolayer assay (IPMA) pada sel MDBK yang diinokulasi dengan sampel positif non-sitopatik BVDV. Sel MDBK membentuk lapisan tunggal dengan tingkat konfluensi 80\%. Pada daerah intrasitoplasmik sel MDBK akumulasi virus non-sitopatik BVDV tampak sebagai agregat berwarna kecoklatan setelah penambahan substart aminoethylcarbasole (positif). (IPMA, 500 kali).

BVDV secara signifikan (hingga 3-5 log /mL) tetapi jika konsentrasi BVDV lebih dari $10^{6} \mathrm{~g}$ eq/mL maka BVDV tetap akan terdeteksi meskipun setelah dilakukan pemanasan dalam waktu yang lama. Hasil tersebut mengkonfirmasi perlunya pengujian secara menyeluruh dalam studi praktis maupun eksperimental karena serum merupakan subjek adanya variasi dalam pembuatan yang mengakibatkan standarisasi produk sulit untuk ditetapkan.

Transmisi BVDV terjadi baik melalui kontak langsung secara horizontal dengan sapi yang terinfeksi atau secara vertikal dari induk ke fetus (Nagayama et al., 2015). Menurut Murray (2006), BVDV mengakibatkan perubahan struktur dari plasenta sehingga organisme patogen tersebut dengan mudah menyeberangi sawar/barrier plasenta dan fetus akan terpapar virus dari induk yang terinfeksi. Virus BVD selanjutnya masuk kedalam sirkulasi darah fetus dan mengakibatkan jaringan serta serum fetus terkontaminasi. Apabila fetus terpapar virus di antara hari ke80 hingga 150 masa kebuntingan yaitu sebelum sistem kekebalan dari fetus berkembang secara sempurna maka fetus tersebut akan terinfeksi secara persisten. Hewan yang terinfeksi secara persisten akan terus terinfeksi sepanjang hidupnya tanpa kemampuan memproduksi respons kekebalan terhadap galur virus yang 
menginfeksi (Murray, 2006; Brodersen, 2014). Tingkat kejadian infeksi persisten BVDV pada fetus dalam masa kebuntingan tersebut berkisar antara 0,5-2,0\%, hal tersebut menggambarkan persentase kejadian yang relatif tinggi (Fulton et al., 2006). Menurut Straver et al. (1983), titer BVDV dalam darah fetus yang terinfeksi secara persisten dapat mencapai $10^{6} \mathrm{TCID}_{50} / \mathrm{mL}$. Apabila diasumsikan bahwa FBS yang diproduksi berasal dari 100 fetus sapi yang lima di antaranya terinfeksi BVDV secara persisten dengan titer virus untuk setiap fetus $10^{6} \mathrm{TCID}_{50}$ $\mathrm{mL}$ darah, maka titer BVDV dalam FBS yang diproduksi akan mencapai $10^{4,7} \mathrm{TCID}_{50} / \mathrm{mL}$ FBS (Daley et al., 1998). Beberapa strategi inaktivasi BVDV dalam bioprosesing antara lain iradiasi gamma, iradiasi UV-C, perlakuan suhu tinggi dengan waktu yang cepat yang diawali dengan pemilihan bahan baku yang baik. Menurut Plavsic et al. (2016), iradiasi gamma merupakan cara yang efektif untuk menurunkan konsentrasi virus yang mengkontaminasi serum. Lebih lanjut dikatakan bahwa iradiasi gamma dengan dosis 25 kilogray mampu menginaktivasi hingga $6 \log \mathrm{TCID}_{50}$. Meskipun demikian, masih ditemukannya BVDV sebagai kontaminan dari produk FBS yang tersedia secara komersial menunjukkan bahwa teknik inaktivasi virus belum dapat menjamin dihasilkannya produk bebas BVDV sepenuhnya (Nims dan Plavsic, 2012). Karena tehnik iradiasi dapat mengakibatkan kerusakan terhadap untaian asam nukleat dari virus maka ketika iradiasi gamma merupakan cara yang dipilih untuk inaktivasi virus, uji analitis yang berbasis asam nukleat seperti PCR sebaiknya tidak digunakan dalam menentukan titer virus (Challener, 2014). Selain hal tersebut, adanya antibodi anti-BVDV dalam FBS juga dapat mengakibatkan hasil negatif palsu karena antibodi dalam serum dapat menetralisasi adanya BVDV sebelum atau sesudah penerapan prosedur inaktivasi virus (Ruppach, 2014). Berdasarkan hal-hal yang diuraikan sebelumnya masih perlu dilakukan penelitian lebih lanjut untuk menemukan bahan tambahan sebagai pengganti FBS dalam teknik kultur sel.

\section{SIMPULAN}

Berdasarkan hasil penelitian terbukti bahwa beberapa sampel FBS yang digunakan di beberapa laboratorium di Universitas Gadjah
Mada secara molekuler positif terkontaminasi BVDV. Uji isolasi terhadap sampel FBS yang positif secara RT-PCR membuktikan bahwa BVDV yang terkandung di dalam sel MDBK tidak bereplikasi.

\section{SARAN}

Penelitian ini merupakan penelitian pendahuluan untuk mendeteksi kemungkinan adanya kontaminasi oleh BVDV pada FBS yang tersedia secara komersial yang hasilnya bervariasi tergantung pada merek dagang, waktu produksi, dan negara yang memproduksi. Berdasarkan hal tersebut disarankan bahwa: 1. Uji tapis/skrining terhadap produk FBS komersial penting dilakukan sebelum digunakan sebelum bekerja dengan virus BVD dan 2. Perlu dikembangkan penggunaan media bebas serum dalam sistem kultur sel.

\section{UCAPAN TERIMA KASIH}

Ucapan terima kasih disampaikan kepada Dirjen Dikti yang telah mendanai penelitian ini melalui BPPTN-BH FKH UGM NOMOR: 994/ J01.1.22/HK4/2019 tanggal 26 Maret 2019.

\section{DAFTAR PUSTAKA}

\section{OIE. 2015. OIE Terrestrial Manual. Bovine Viral} Diarrhea. Chapter 2.4.8. Paris, France.

Bauermann FV, Ridpath JF, Weiblen R, FloresEF. 2013. HoBi-like viruses: An emerging group of pestiviruses. J Vet Diagn Invest 25(1): 6-15.

Bazid AI， Nayel M, El-Sify A. 2015. Molecular diagnosis and genotyping of bovine viral diarrhea virus. J Curr Vet Res 15(2): 112 118.

Brodersen BW. 2014. Bovine viral diarrhea virus infections: manifestations of infection and recent advances in understanding pathogenesis and control. Vet Pathol 51(2): 453-464.

Daley JP, Danner DJ, Weppner DJ, Plavsic MZ. 1998. Virus inactivation by gamma irradiation of fetal bovine serum. Focus 20: 86-88. 
Darweesh MF, Rajput MK, Braun LJ, Ridpath JF, Neill JD, Chase CCL. 2015. Characterization of the cytopathic BVDV strains isolated from 13 mucosal disease cases arising in a cattle herd. Virus Res 195: 141-147.

El-Dakhly AT, Youssef MM, Abeer AT, Hussein AHM. 2015. Comparative studies on media supplementation with various types of sera in tissue cultures. Am J Res Com 3(12): 4961.

Fulton RW, Whitley EM, Johnson BJ, Ridpath JF, Kapil S, Burge LJ, Cook BJ, Confer AW. 2006. Prevalence of bovine viral diarrhea virus (BVDV) in persistently infected cattle and BVDV subtypes in affected cattle in beef herds in south central United States. Can J Vet Res 73: 283-291.

Glangaspero M. 2013. Pestivirus species potential adventitious contaminants of biological products. Trop Med Surg 1(6): 153-156.

Hawkes PW. 2015. Fetal bovine serum: geographic origin and regulatory relevance of viral contamination. Bioresour Bioprocess 2(34): 1-5.

Kozasa T, Aoki H, Nakajima N, Fukusho A, Ishimaru M. 2011. Methods to selest suitable fetal bovine serum for use in quality control assays for the detection of adventitious viruses from biological products. Biologicals 39: $242-248$.

Mahmood A, Ali S. 2017. Microbial and viral contamination of animal and stem cell cultures: Common contaminants, detection and elimination. J Stem Cell Res Ther 12(5): 149-155.

Monteiro FL, Cargnelutti JF, Braunig P, Folgueras-Flatschart AV, Santos NC, Pituco EM, Weiblen R, Flores EF. 2018. Detection and genetic identification of pestiviruses in Brazilian lots of fetal bovine serum collected from 2006 to 2014. Pesq Vet Bras 38(3): 387 392.

Murray RD. 2006. Practical approach to infectious bovine abortion diagnosis. World Buiatrics Congress XXIV. Nice, France. https://citeseerx.ist.psu.edu/viewdoc/ download? doi=10.1.1.582.2021\& rep= rep $1 \&$ type $=$ pdf
Nagayama K, Oguma K, Sentsui H. 2015. Survey on vertical infection of bovine viral diarrhea virus from fetal bovine sera in the field. J Vet Med Sci 77(1): 1531-1534.

Nims R, Plavsic MZ. 2012. The pervasiveness of bovine viral diarrhea virus in commercial bovine serum. Bioprocessing $J$ 11(4): 1926.

Plavsic $M Z$, Nims R, Wintgens $M$, Versteegen R. 2016. Gamma irradiation of animal serum: Validation of efficacy for pathogen reduction and assessment of impacts on serum performance. Bioprocessing $J 15(2)$ : 12-21.

Polak MP, Rola J, Zmudzinski JF. 2008. Contamination of foetal bovine serum with bovine viral diarrhoea virus (BVDV). Bull Vet Inst Pulawy 52: 501-505.

Ruppach H. 2014. Log10 reduction factors in viral clearance studies. Bioprocessing $J$ 12(4): 24-30.

Sudarisman. 2011. Bovine Viral Diarrhea pada sapi di Indonesia dan permasalahannya. Wartazoa 21(1): 18-24.

Straver PJ, Journee DLH, Binkhorst GJ. 1983. Neurological disorders, virus persistence and hypomyelination in calves due to intrauterine infections with bovine virus diarrhea virus. II, Virology and epizootiology. Vet Quarterly 5: 156-164.

Supriyadi A, Hutagaol NM, Karyanti D. 2008. Situasi penyakit bovineviral diarrhea di Kalimantan berdasarkan pengujian ELISA. Konferensi Ilmiah Veteriner Nasional X. Perhimpunan Dokter Hewan Indonesia. Bogor, 18 Oktober 2008.

Uryvaev LV, Dedova AV, Dedova LV, Ionova KS, Parasjuk NA, Selivanova TK, Bunkova NI, Gushina EA, Grebennikova TV, Podchernjaeva RJ. 2012. Contamination of cell cultures with bovine viral diarrhea virus (BVDV). Bull Exp Biol Med 153(1): 77-81.

Vilcek S, Herring AJ, Herring JA, Nettleton PF, Lowings JP, Paton DJ. 1994. Pestivirus isolated from pigs, cattle and sheep can be allocated into at least three genogroups using polymerase chain reaction and restriction endonuclease analysis. Arch Virol 136: 309-323. 
Wasito R, Sardjono B, Wuryastuti H, Isrina SOS, Yuriadi. 1992. Uji serologic Bovine Viral Diarrhea dengan teknik EnzymeLinked Immunosorbent Assay. Laporan Penelitian, PAU, Bioteknologi, Universitas Gadjah Mada, Yogyakarta, Indonesia.

Wuryastuti H. 2018. Deteksi molekular kontaminasi bovine viral diarrhea virus pada serum hewani komersial untuk kultursel. Laporan akhir kegiatan penelitian hibah penelitian pengembangan departemen, Fakultas Kedokteran Hewan, UGM.

Wuryastuti H, Wasito R, Sugiyono. 2018. Genotypes and biotypes variation of bovine viral diarrhea virus from persistenty infected dairy Cattle in Java, Indonesia. Integr J Vet Biosci 2(3): 1-7.

Xia H, Larska M, Giammarioli M, DeMia GM, Cardeti G, Zhou W, Alenius S, Belak S, Liu L. 2013. Genetic detection and characterization of atypical bovine pestiviruses in foetal bovine sera claimed to be a Australian origin. Transbound Emerg Dis 60(3): 284288.

Zabal O, Kobrak AL, Lager IA, Achudel AA, Weber EL. 2000. Contamination of bovine fetal serum with bovine viral diarrhea virus. Rev Argent Microbiol 32(1): 27-32. 